\title{
Plant Latex, from Ecological Interests to Bioactive Chemical Resources*
}

\author{
Authors \\ Affiliations \\ 1 Institute of Biology, Leiden University, Leiden, \\ The Netherlands \\ 2 College of Pharmacy, Kyung Hee University, Seoul, \\ Republic of Korea \\ Key words \\ plant exudates, latex coagulation, mechanical defense, \\ bioactive latex metabolites, endophytes, interaction \\ received February 28, 2019 \\ revised May 15, 2019 \\ accepted May 16, 2019 \\ Bibliography \\ DOI https://doi.org/10.1055/a-0923-8215 \\ Published online May 28, 2019 | Planta Med 2019; 85: 856- \\ 868 @ Georg Thieme Verlag KG Stuttgart · New York I \\ ISSN 0032-0943 \\ Correspondence \\ Dr. Young Hae Choi \\ Institute of Biology, Natural Products Laboratory, \\ Leiden University \\ Sylviusweg 72, 2333 BE Leiden, The Netherlands \\ Phone: + 315274510 , Fax: + 315274511 \\ y.choi@chem.leidenuniv.nl
}

Luis Francisco Salomé Abarca ${ }^{1}$, Peter G. L. Klinkhamer ${ }^{1}$, Young Hae Choi ${ }^{1,2}$

\section{ABSTRACT}

Historically, latex-bearing plants have been regarded as important medicinal resources in many countries due to their characteristic latex ingredients. They have also often been endowed with a social or cultural significance in religious or cult rituals or for hunting. Initial chemical studies focused on the protein or peptide content but recently the interest extended to smaller molecules. Latex has been found to contain a broad range of specialized metabolites such as terpenoids, cardenolides, alkaloids, and phenolics, which are partly responsible for their antibacterial, antifungal, anthelmintic, cytotoxic, and insect-repellent activities. The diversity in biology and chemistry of latexes is supposedly associated to their ecological roles in interactions with exogenous factors. Latexes contain unique compounds that are different to those found in their bearing plants. Exploring the feasibility of plant latex as a new type of bioactive chemical resource, this review paper covers the chemical characterization of plant latexes, extending this to various other plant exudates. Also, the factors influencing this chemical differentiation and the production, transportation, and chemistry of the latex exudates are described, based on ecological and biochemical mechanisms. We also proposed a latex coagulation model involving 4 general conserved steps. Therefore, the inherent defensive origin of latexes is recognized as their most valuable character and encourages one to pay attention to these materials as alternative sources to discover metabolites with insecticidal or antimicrobial activity.

\section{Introduction}

Latex is a milky fluid consisting of tiny droplets of organic matter dispersed in an aqueous medium (a sort of natural colloidal suspension). Based on their physicochemical characteristics there are many subtypes of latexes, but the most well-known ones are rubbery latexes, of which polymeric microparticles can reach over $50 \%$ of the latex weight. If boiled, latexes can often coagulate, forming a solid mass. The main constituents of the coagulum are cis or trans-polyisoprenes and resinous materials [1,2]. Additionally, they also contain diverse primary and specialized metabolites as well as considerable levels of polypeptides and proteins. Compared with other types of plant exudates, latexes have a high degree of chemical diversity, not merely at the level of analogues of individual compounds but as a broad range of chemical classes. These chemical characteristics distinguish latex from other plant exudates. In plants, latex is reported to be ubiquitous in more than 20000 species from over 40 families of angiosperms, which represents between 8 and $10 \%$ of all of the terrestrial angiosperms [3-6]. Among these, most studied plants belong to the Asclepiadaceae, Sapotaceae, Anacardiaceae, Apocynaceae, and Euphorbiaceae families [1,7]

The biological roles of latex are associated with many exogenous factors. Because of their chemical selection and mutual in-

* Dedicated to Professor Dr. Cosimo Pizza 70th birthday in recognition of his outstanding contribution to natural product research. 
teraction of components related to their dedicated biological functions, plant latexes have been considered the first line of defense against many herbivores and pathogens $[5,8,9]$. It is possible even that microorganisms living inside a host plant, so-called endophytes, could be involved in the production and biotransformation of a broad range of host plant-originated metabolites related to defensive strategies $[10,11]$. Therefore, the complex factors involved in the production of latex metabolites, together with plant biosynthesis, result in the chemical discrimination of the latex metabolome from that of other parts of the plant, showing a great potential as a new bioactive chemical resource.

Looking into the feasibility of plant latex as a new type of resource of active chemicals, this review paper deals with the chemical characterization of plant exudates in the first part and then later focuses on plant latexes and how their chemical composition generally differs from their bearing plants. Moreover, to investigate the factors influencing this chemical differentiation, the production, transportation, and chemistry of the exudation of latex are described from an ecological and biochemical mechanism perspective. Lastly, an insight for the use of latexes as a bioinspirational model are discussed, which could partly explain metabolite selection, their complementation as bioactive mixtures in plants, and their potential application in medical and crop sciences.

\section{Characterization of Plant Latex and Other Exudates}

In addition to latex, plants produce several types of exudates such as gums, mucilage, essential oil, oleoresins, resins, and phloemlike saps [1]. The differentiation of exudates is mainly associated with species specificity, anatomical origin, morphological appearance, or their chemical composition. Nonetheless, plant exudates are generally classified based on their chemical composition ( $\triangleright$ Fig. 1).

Gums are defined as solids usually produced from stem barks or roots. They flow out naturally upon mechanical damage or at an infection point, readily solidifying on contact with air [2]. The main constituents of gums are polysaccharides, which are polymers of arabinose, galactose, mannose, and glucuronic acid [1]. They are thus hydrophilic, being either water-soluble or capable of absorbing water and swelling up to form a gel, but they are insoluble in oils or organic solvents.

Mucilages are water-soluble acidic or neutral polysaccharides that yield mixtures of simple sugars (e.g., galactose, arabinose, xylose, rhamnose, and galacturonic acid) or uronic acid $[2,12$, 13] by hydrolysis. The localization of mucilages is very specific, being produced intracellularly and having some of their constituents related to cell wall components [14]. Differently to gums, mucilages are strongly related to seed survival and also act as water storage in plants [14].

Oleoresins are referred to as resins or, more specifically, soft resins. They are exudates with a high content of volatile compounds. The physical state of a resin varies from solid to semi-solid, being composed of lipophilic terpenes such as mono-, sesqui-, and diterpenes. While most plants can produce resins, only a few

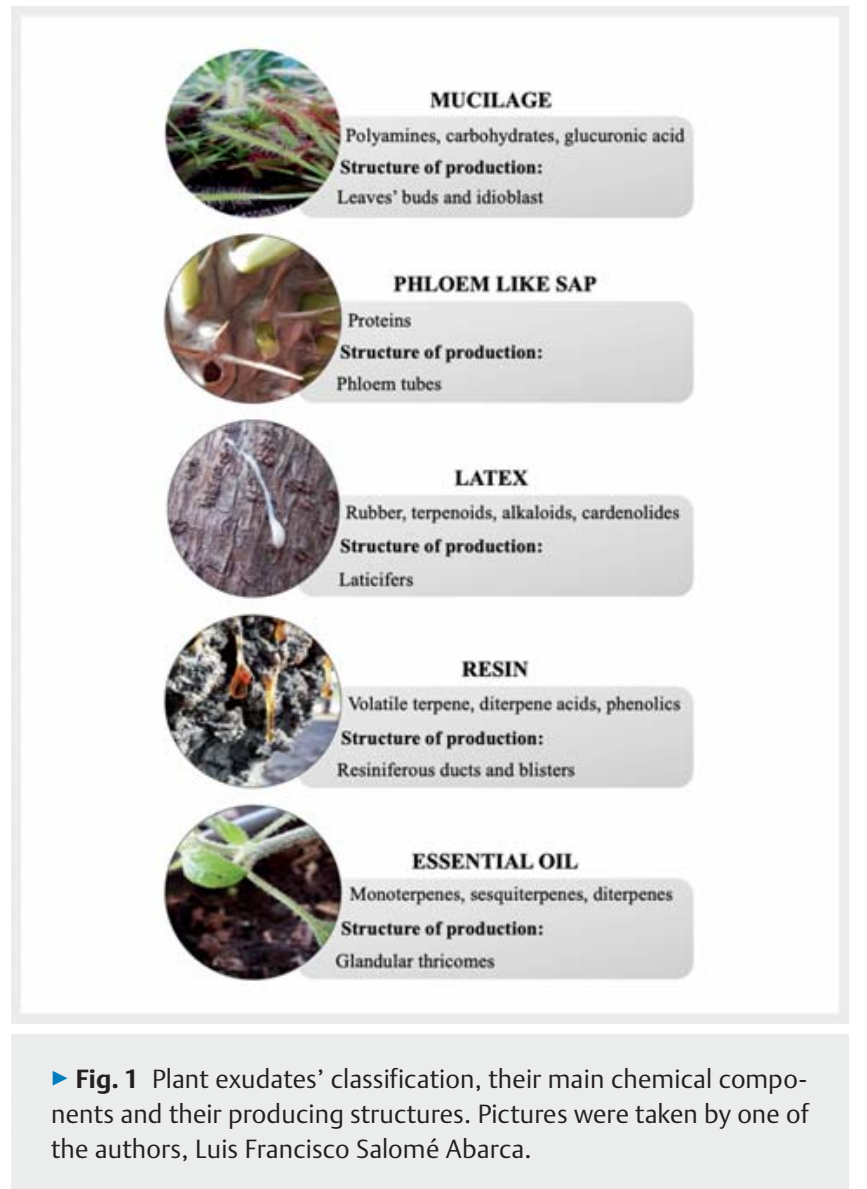

families such as Fabaceae, Burseraceae, and Pinaceae are known for their high resin production [1].

Essential oils are mainly composed of organic volatile compounds, which confer their characteristic properties such as odor and density and low melting points [15]. Unlike other types of plant exudates, their vapor pressure under atmospheric conditions is so high that they diffuse through the air $[16,17]$. These volatile compounds belong to various chemical classes such as alcohols, ethers or oxides, aldehydes, ketones, esters, amines, amides, phenols, heterocycles, and mainly monoterpenes [16].

Extra fascicular phloem is a particular type of sap localized in a special network of sieve tubes outside of the vascular bundles. It is found in a very limited number of families such as Curcurbitaceae $[18,19]$. They contain abundant amino acids and a wide range of low levels of small molecules together with some proteins [20]. The biological functions of the phloem are likely associated with their proteins such as instant wound signaling and plugging of the sieve elements to avoid the loss of nutrients. They have additionally been found to play a direct role as anti-insect agents against generalist insect-herbivores [21].

The definition of latex has varied throughout time according to the review paper by Hunter (1994) [22]. Polhamus (1962) stated that "no one has demonstrated why a plant makes rubber and it does not appear to be a food reserve. Strong evidence indicates that rubber is an end-product that is not reused in the metabolism of the plant" [23]. Five years later Metcalfe (1967) stated, "The 


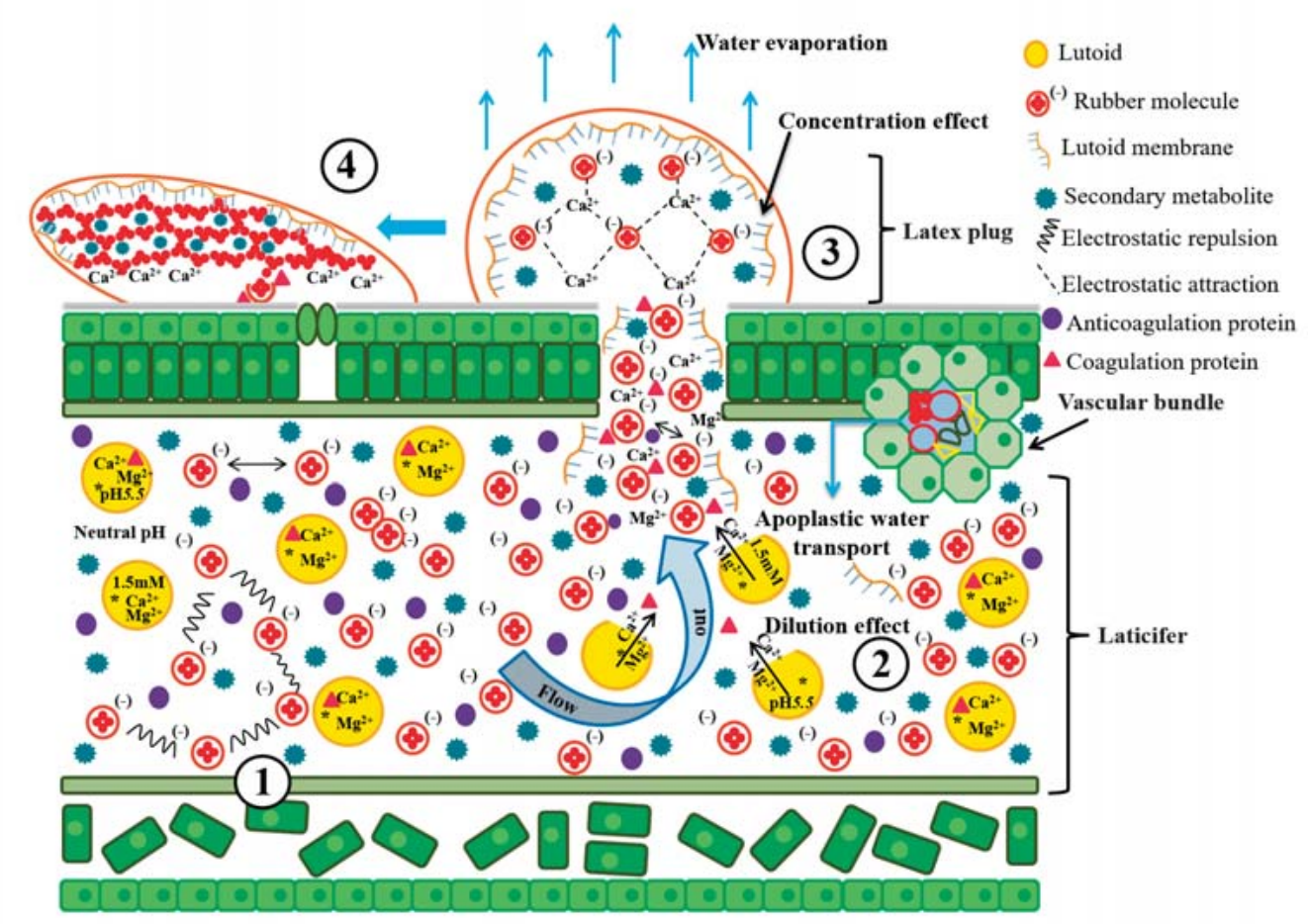

- Fig. 2 A model of latex coagulation process. Four main steps are represented: (1) equilibrium state, (2) laticifer rupture, (3) plug formation, and (4) plug polymerization.

term latex is used loosely by plant anatomists for fluids with a milky appearance due to the suspension of many small particles in a liquid dispersion medium with a very different refractive index" [24]. Further, he added, "According to Esau (1965) the dispersed particles are commonly hydrocarbons of the terpene type which include essential oils, balsams, and rubber." Moreover, "The fact that latex is restricted to a small number of plant families which have little taxonomic relationship suggests that the capacity to produce latex has been evolved more than once" [25]. Even after all these concepts and hypothesis, Webster and Baulk will (1989) concluded that "as none of the above hypotheses has been proven, the function of latex and rubber in the plant remains unknown" [26].

Nowadays, there are more definitions of latex, based on their anatomical origin, storage, or ecological roles. Particularly, the ecological approach explains possible functions of latex in plants. For example, Konno (2011) stated that "plant latex is a sap, typically a white sap, that is stored in the tissue called a laticifer and that is exuded from a point of damage in plant tissues immediately after insect herbivory" [5]. Currently, latex can be defined in a general manner, as an exudate that is kept in extremely elongated cells extended along the plant. Such canal structures are called laticifers. Anatomically, latexes are originated from vacuoles because a large part of the laticifer cells are occupied by vacuoles [27].

A number of phytochemical studies investigating latex biochemistry have been published, covering complex aqueous mixtures of rubber to specialized metabolites such as alkaloids, cardenolides, phenolics, starch, furanocoumarins, sugars, and non-protein amino acids $[4,28,29]$. However, most previous works focused on polymeric ingredients while specialized metabolites were usually neither properly identified nor quantified. If any, research was done on a limited number of species (e.g., on the latex of Taraxacum officinale L., Asteraceae) [6].

Currently, there is no scientific evidence of the metabolic role of latex in plants. Instead, a large amount of evidence has been accumulated proposing latex as a natural defense barrier against herbivores. In the strict sense, a plant defense is any feature that improves the fitness of plants under herbivory pressure [30]. In the case of latex, it is used by plants as a complementary chemical and mechanical defensive system [31] ( $\triangleright$ Fig. 2). However, only a few studies have linked the variation of latex in planta to plant fitness [32].

\section{The composition of latexes}

Laticifers are specialized latex-producing cells with a characteristic anatomy and distinct cytoplasm [33]. The cytoplasm of the cells is a colloidal suspension of small particles in an aqueous sap of unspecified composition, but normally with different refractive index from its particles $[34,35]$. They contain latexes that are generally milky or white but may sometimes be colored (yellow, orange, red, brown) or even colorless [36].

The mature laticifer has not yet been reported to contain chloroplasts [37] so it is believed to have no functional plasmodesmatal connections with its neighboring tissues. Thus, laticifer cells are expected to obtain their energy from the apoplast. Hence, its 
electrophysiological behavior might display an electrogenic sequelae of active transport. Specifically, the loading of laticifers is thought to be related to the symplastic transport of photoassimilates and other minerals, from the phloem to the contiguous associated parenchyma. This process is followed by their entrance to the apoplast, and further transport into the laticifer by an $\mathrm{H}^{+}$/sugar symport system $[36,38]$ to be transformed into latex.

\section{Lutoids and Frey-Wyssling complexes}

The ultracentrifugation of latex at $59000 \mathrm{~g}$ yielded 3 major fractions [39]. The bottom layer consisted in a solid pellet corresponding to around $20 \%$ of the latex volume, a rubber-clear aqueous supernatant (C-serum) mid-layer, and an upper layer consisting of rubber particles that floated to the top [39]. The bottom fraction was characterized by the presence of a special type of plastids, called lutoids [40]. Electron microscopy shows them as spherical particles ranging in size from 0.5 to $3.0 \mu \mathrm{m}$. Lutoids are highly osmosensitive [41]. Lutoids accumulate chemicals from the cytoplasmic environment. Some of these, specifically pyrophosphate (Pi), citrate, and $\mathrm{Mg}^{2+}$ are about 10 times more concentrated than in the cytoplasm. They also contain many amino acids, acid hydrolases, peroxidases, lysozyme, and $\alpha$-mannosidase [42]. Lutoidic membranes were reported to have a low or undetectable content of phosphatidic acid and no nitrogen phospholipids [43], while both types of compounds were detected in the membrane of rubber particles. It was hypothesized that the large quantity of negative charges carried by the phosphatidic acid favors the colloidal stability of the main chemical components present in latex $[42,43]$.

Similar sensitive particles to lutoids can be found as a thin vivid yellow layer conform of specialized plastids. These layers are form by double membrane vesicles that contain carotenes and polyphenol oxidases (PPOs) [44]. These modified plastids, so-called Frey-Wyssling complexes, contribute to the coagulation of latex under open-air conditions because of their 0 -diphenoloxidase content [41]. This activity is related to the oxidation of 0 -diphenols to o-quinones [45]. These transformed metabolites can react with a big variety of substances in the cytosol such as proteins or oligosaccharides to form brown polymers. These phenomena are well documented in T. officinale latex L. (Asteraceae) [46].

\section{Rubber}

Rubber is a biopolymer with exceptional properties such as high elasticity, resilience, and efficient heat dispersion [47]. This polymer is synthesized from cis-isopentenyl diphosphate units, poly-(cis-1,4-isoprene ( $\bullet$ Fig. 3 A) [48-50]. These polymers in rubbery latexes are present in the form of globules surrounded by a phospholipoprotean membrane [41]. According to Agrawal and Konno (2009), the stickiness of latex is attributed mainly to factors related to rubber: (a) elasticity of cis-polyisoprene, (b) coagulation of rubber particles, and (c) adhesiveness of rubber particles to the surfaces of insects. Therefore, the primary role of rubber in latex that is generally accepted is to confer self-stickiness [4]. In addition to the stickiness, the white color of latexes is also due to the rubber particles [51].

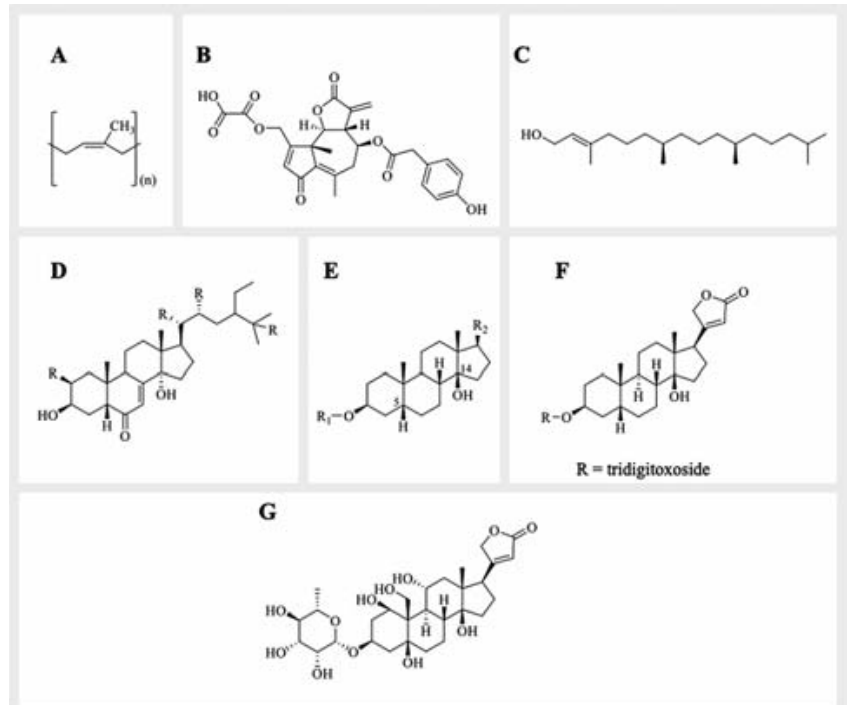

- Fig. 3 Chemical structures of typical terpenoids and steroids found in latexes. A cis-1,4-polyisoprene, B lactucopicrin oxalate, C phytol, D phytoecdysones, E cardenolides $(5 \beta, 14 \beta$-androstane$3 \beta, 14$-diols), $\mathbf{F}$ digitoxin, and $\mathbf{G}$ ouabain.

\section{Proteins and enzymes}

A variety of proteins and enzymes have been isolated and identified from plant latexes. Of the numerous identified proteins, cysteine proteases, serine proteases, chitinases, lectins, protease inhibitors, and oxidases are the most reported in literature [52]. These proteins play many physiological roles such as signal transduction and oxidative defense $[53,54]$. Due to the variety of proteins, latexes were assumed to be a promising reservoir of defense proteins [5], providing a strong evidence of their defensive role against the plant's natural enemies. Intriguingly, some of the proteins were found to possess not only direct toxicity for the enemies but were also capable of triggering a mechanical defense against herbivores (e.g., coagulation process to form an initial barrier) [55-57].

In the latex of Chelidonium majus L. (Papaveraceae) cystains (thiol protease inhibitors) were determined to be involved in stress adaptation mechanisms and defense plant responses. Moreover, these enzymes could also confer antimicrobial and antiviral properties to this latex [58]. Moreover, in some plant species, the functions of these proteins were related to specialized metabolites such as alkaloids [59].

Besides, the construction of a comprehensive dataset containing 1208 nonredundant latex proteins from diverse latex producing species and its in silico predictions showed latex proteins to be related to a broad range of internal molecular processes and also to external environmental changes. Further, the function similarity between latex and phloem proteins suggested a functional conservation in plant vascular proteins [60]. Also, latex proteins have been reviewed and liked to a new type of constitutive immediate response against viral agents [61].

Lectins are natural specific carbohydrate-binding proteins and similarly to these exert a protective function against a wide range of pests $[62,63]$, including homopteran, lepidopteran, and co- 
leopteran insects [64-66]. A review of literature on this activity reveals different possible mechanisms, one of the most important being their stability in the digestive system of herbivores [63]. They also displayed a significant inhibitory activity of protein synthesis as exemplified with an in vitro test with 2 lectins isolated from the latex of Hura crepitans L. (Euphorbiaceae) [67]. Another report showed them to be effective against sucking insects because of their specific residues that show mannose-binding to cell walls [64]. They are also able to act indirectly against herbivores by enhancing latex coagulation [57] unlike other types of proteins that can only act as a direct chemical defense.

Another relevant type of latex proteins are protein inhibitors since they can confer anti-nutritive properties to the latex (e.g., protease inhibition to prevent protein digestion) [68]. Trypsin and serine protease inhibitors were found to be highly induced in the latex of Ficus carica L. (Moraceae) [69] and Carica papaya L. (Caricaceae) upon herbivore and pathogenic microbes' attacks [70]. This type of molecule can counteract degradative enzymes produced by some microorganisms during pathogenic interactions or by other specialized insects. The complexity of the enzymatic biochemical system in the latex of Euphorbia species has been discussed previously by Pintus et al. [52].

\section{Specialized metabolites in latex}

In general, plants have 2 types of defense systems, primary and secondary. Primary defenses are the first line of defense against herbivore attacks and involve morphologically protective structures on the surface, such as hairs, trichomes, thorns, spines, or even thicker leaves. Secondary defenses are considered to be mediated by plant chemicals, especially by specialized metabolites (e.g., phenolics, terpenoids, and alkaloids). The metabolites induced during plant defense can directly kill or retard the development of the herbivores and phytopathogenic microorganisms [71]. The main defensive role of plant exudates is very likely as a barrier: acting firstly mechanically rather than chemically because of their inherent stickiness or sliminess. These exudates are able to tangle some herbivores by reducing their movements or disabling their mouthparts and sense organs [72]. They can also seal wounds, preventing the entrance of possible pathogens [73]. On the other hand, a specific type of exudates such as latex, phloemlike sap, and resins can exert a secondary type of chemical defense due to their wide range of specialized metabolites as well as functional proteins that are frequently in much higher concentrations than in other organs or tissues of the plant, such as leaves, stems, or roots [4]. It has been found that many of these compounds provide strong resistance to herbivores via toxicity or anti-feeding effects [5].

In many latexes, the local concentrations of defensive substances increase at the point of damage to levels estimated to be between 20 and 2000 times those in leaves [74-76]. In this sense, latex is similar to an inducible defense system despite being preformed in the plant. However, there is a great advantage in latexborne defense, since the local increase of the level of specialized metabolites occurs within a few seconds after herbivory, which is much faster than inducible defense systems [5]. The advantage of the latex response is even greater considering the mobility that allows for the immediate transport of defense substances to the precise point of damage by herbivores or pathogenic infections [5]. It is thus a perfect example of the complementation of primary and secondary defenses.

Plant latexes have been found to display a broad chemical diversity that, as mentioned before, is distinctive from other organs or exudates of the plant. Their chemical uniqueness is not limited to a specific group of metabolites but includes a wide range of specialized metabolites such as terpenes, phenolics, alkaloids, and cardenolides $[4,28,29]$. Furthermore, some multitask and biologically active proteins including cysteine and serine proteases, and several other enzymes have been also found in these exudates [52].

\section{Terpenoids and steroids}

One of the most abundant metabolites in latexes is a polymeric terpenoid derived from isoprene units (C5). The most important C5 compound in latex is rubber (cis-1,4-polyisoprene) ( $\bullet$ Fig. 3 A). This compound is found in many plant species (i.e., 300 genera and 8 plant families) [22,51,52].

Apart from rubber, smaller terpenoids have also been found in latex. The latex of Lactuca sativa L., Asteraceae, contains several sesquiterpene lactones. In particular, the concentration of lactucopicrin oxalate ( $\vee$ Fig. $\mathbf{3 B}$ ) in latex was found to be 1000 times higher than in leaves. Together with these sesquiterpene lactones, lettucenin A was reported to be induced in latex by fungal or bacterial challenge [77]. The involvement of the induced compounds in plant defenses was partially supported by some antifungal activity against Cladosporium herbarum $[4,78]$. Some Euphorbiaceae latexes (e.g., Euphorbia biglandulosa Desf., Euphorbiaceae) contain diterpenes, phorbols, and their derivatives in higher concentrations than in other organs [78]. These compounds exhibit a high toxicity against many insects and mammals [79]. Further, phytol ( $\vee$ Fig. $3 \mathbf{C}$ ), which is found in chlorophyll as a side chain, is supposed to help some compounds to adhere to cell membranes [80]. Steroids, particularly phytoecdysones ( $\vee$ Fig. 3D) have some defensive roles against insects, disrupting molting and other developmental and physiological processes with lethal consequences [81].

Euphorbia is a genus that is well-known to contain triterpenoids as the major components of their latexes [82]. For example, the latexes of Euphorbia officinarum L. (Euphorbiaceae) and Euphorbia peplus L. (Euphorbiaceae) were found to have several steroids and triterpenes including obtusifoloiol, cycloartenol and 24-methylenecycloartenol, lupeol, lupeol acetate, lanosterol, and 24-methylenelanosterol, among others [83]. The biological roles of the steroids and the triterpenoids are still unclear, although they are always present in high levels in rubbery latexes. As an assumed role, these compounds could form part of the laticifer or the lutoidic membrane or even could be freely suspended in the C-serum. This could imply that the latex steroids and terpenoids might attach to the cell membranes of herbivores or pathogens, consequently facilitating the transportation of non-lipophilic molecules through cell membranes of insects or microorganisms. They could be intercalated in the cell membranes, forming channels that allow the entrance of small toxic hydrophilic molecules such as phenolics or others [84]. 
Another specific type of steroids, cardenolides, a type of cardiac glycoside that has a 5 - or 6 -membered lactone ring in $\beta$ position at $\mathrm{C} 17$, are also well-known metabolites in latexes. The cardenolides are able to inhibit $\mathrm{Na}^{+} / \mathrm{K}^{+}$-ATPases, which are essential for maintaining the electric potential in most animal cells [5, 85]. Cardiac glycosides have 3 characteristic molecular features: sugar, steroid, and lactone moieties. Lactone rings and sugar moieties are not likely to be essential parts for their biological activity [86, 87]. However, these lactone and sugar moieties could also be involved in the interaction with the $\mathrm{Na}^{+} K^{+}$-ATPase inhibition process [88]. Studies on structure-activity relationships of cardenolide toxicity in animals revealed their steroid nucleus $5 \beta, 14 \beta$-androstane-3 $\beta$,14-diol ( $\triangleright$ Fig. $3 \mathbf{E}$ ) as the structure required for receptor recognition [87]. Further, the differences in the hydrophilicity of cardenolides is associated with the degree of absorption by animal tissues, which consequently resulted in potential toxicity. Usually, lipophilic cardenolides like digitoxin ( $\bullet$ Fig. 3 F) are rapidly and almost completely absorbed but polar ones such as ouabain ( $\vee$ Fig. 3G) are slowly absorbed in the intestine [86]. In the case of herbivory, cardenolides can also avert insect egg-laying and herbivory and disrupt their development, especially for generalist insects [89-94].

The latexes of many Apocynaceae plants, another main latexbearing family, contain high levels of cardenolides (up to $30 \%$ considering the latex dried mass) $[74,85]$. For example, the latex of Antiaris toxicaria Lesch. (Moraceae) in tropical Southeast Asia have cardenolides (toxicariosides). Interestingly the cardenolides in the latex are very different from those of the leaves [95, 96]. Although the unique pattern of cardenolides in the latex might result from the specific selection for defense compounds to be located in latex as a defensive trait, more studies are required to prove these roles.

\section{Phenolics}

Many types of phenolics, usually synthesized in the shikimate pathway, are ubiquitous in plants (e.g., tannins, lignans, coumarins, anthraquinones, phenylpropanoids, and flavonoids). It is thus expected that these diverse phenolics are involved in many biological and physiological processes of plants in general [97]. While the ecological significance of phenolics is undoubted, their presence in latexes has not been studied extensively. One study reported the presence of gallic acid, naphthoic acid, quercetin, chlorogenic acid, and rutin in the latex of Hevea brasiliensis (Willd. ex A. Juss.) Müll. Arg. (Euphorbiaceae) [98] while higher levels of hexadecyl, octadecyl, and eicosyl esters of $p$-coumaric acids ( $\triangleright$ Fig. 4A) were found in the latex of sweet potato, Ipomoea batatas (L.) Lam. (Convolvulaceae), as compared to those of other organs. Similar results were observed in fresh vine latex and root latex that showed a $3 \%$ and $10 \%$ higher content of $p$-coumarate esters than leaves and roots, respectively [99]. Interestingly, the concentration of this type of coumarins (e.g., C16, C18, C20 (Z)coumarates) is inversely correlated to the palatability for weevils. Thus, (Z)-coumarate esters are assumed to participate in the defense of sweet potato against insect herbivores [99]. The latter would support the role of latex as a defense strategy.

Oxidative activation may explain much of the variation observed at the individual and ecosystem level responses to phe-

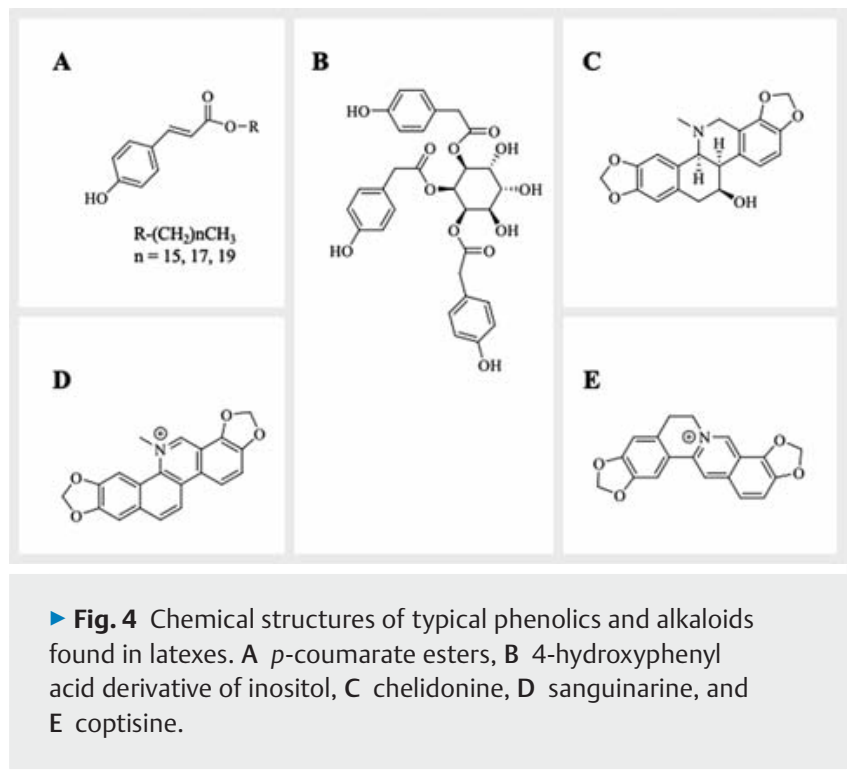

nolics [97]. Phenolic inositol esters ( $\vee$ Fig. 4B) were found to be 1 of the 3 major predominant metabolites classes in leaves, roots, and especially latex of 3 genotypes of dandelion ( $T$. officinale agg. L., Asteraceae), and again in this case, the metabolites in latex were strongly repellent against generalist insects as compared to those of leaves and roots [6].

Based on these results, it can be assumed that a certain phenolic compound plays a specific role in latex. This is also supported by the fact that their oxidative activation is perfectly matched with the hypoxic conditions in the laticifer, therefore preventing pre-activation and self-plant intoxication. Furthermore, it is known that many fungi produce oxidases as detoxification mechanisms against plants, but in this case this fungal strategy could in fact activate and potentiate the biological activity of phenolic compounds.

\section{Alkaloids}

Alkaloids are the most bioactive group of specialized metabolites found in nature. Even if many plant organs contain these compounds, especially high concentrations are found in young organs [100]. Their main function in plants is to work as defensive compounds against herbivores, especially mammals, because of their wide range of toxic effects and deterrence capability [101-103]. Some alkaloids disrupt the nervous system, especially chemical transmitters, while others can affect membrane transport, protein synthesis, and miscellaneous enzyme activities [70,104]. Many types of alkaloids are found in plant exudates. They are irregularly distributed and highly concentrated amongst angiosperm families, including Apocynaceae, Papaveraceae, and Moraceae. For example, isoquinoline alkaloids such as chelidonine ( $\vee$ Fig. 4C), sanguinarine ( Fig.4D), and coptisine ( Fig. 4E) can reach almost $20 \%$ of the fresh latex mass in C. majus L. (Papaveraceae) [105]. Sanguinarine is especially toxic to insects and vertebrates because of its capability to affect neurotransmission, several neuroreceptors, and DNA synthesis $[4,106]$.

In general, most alkaloids have some degree of toxicity and appear to be used by plants in defense against herbivores and path- 
ogenic microorganisms. Therefore, latexes could constitute an important site for the production or storage of these compounds. In fact, some enzymes involved in the first stages of alkaloidal production are contained in parenchymal cells proximate to laticifer cells [107] and those involved in their final biosynthetic phases are contained in the laticifer cytoplasm [108]. Alkaloids in latexes are believed to have many biological roles, but to date there are not yet many reports to support such allegations. One of the few studies explored a possible mechanism of sugar-mimicking alkaloids. These imino-sugars are powerful inhibitors of glycosidases and other essential enzymes related to sugar metabolism in insects [109]. They were found in the latexes of mulberry (Morus spp., Moraceae) at levels as high as $2.5 \%$ of the latex fresh mass and $18 \%$ of the dry mass [76]. Additionally, these alkaloids were found to be related to poor development of insects by growth disruption because of the inhibition of sucrose uptake and trehalose usage in several tissues [110].

\section{Physical and Chemical Implications in Latex Transportation and Coagulation}

\section{Latex transportation}

Latex is immediately mobilized to the site of damage after either mechanical or herbivore damage. The latex of Cryptostegia grandiflora Roxb. ex R. Br. (Apocynaceae) was reported to be transported within the plant over a distance of more than $70 \mathrm{~cm}$ to a damaged point [111]. The non-punctured laticifer is turgid probably due to osmotic water uptake, which could contribute to the out flow of latex whenever the laticifer is broken by any type of tissue disruption. Qualitative observations on Euphorbia species showed that the recovery of the normal laticifer oozing pressure takes around $1 \mathrm{~min}$ [112]. However, the process of emptying and refilling of single laticifers has not been accurately measured yet [112].

Another fact that supports the role of latex in defense instances is that the amount of the exuded latex can increase in response to insect herbivory. For example, herbivory by the larvae of the monarch butterfly (Danaus plexippus) on 2 Asclepias species resulted in an almost 2-fold increment in the amount of exuded latex $[4,113,114]$. However, the laticifer-borne system is very susceptible to damage, especially when ducts in the proximal areas are destroyed. In such cases, the leaf area that is distant to the point of destruction has no supply of latex from the main reservoir in the proximal parts and also loses pressure to exude latex [5].

\section{Chemical coagulation: a physiological role of latex in plants}

The coagulation process of latex has been extensively studied due to its practical importance as it is the main limiting factor in rubber extraction for its utilization on industry. In the case of $\mathrm{H}$. brasiliensis (Willd. ex A. Juss.) Müll. Arg. (Euphorbiaceae), one of the most well studied plants for rubber extraction, Gidrol et al. (1994) proposed that hevein, a lectin-like protein, might be involved in the coagulation of latex [56]. Later on, a new anticoagulating factor in the $\mathrm{C}$-serum of $\mathrm{H}$. brasiliensis (Willd. ex A. Juss.)
Müll. Arg. (Euphorbiaceae) latex was discovered [57]. This factor, called hevea latex lectin ( $\mathrm{HLL})$, reinforced the previous model of latex coagulation. The HLL binding affinity to the soluble C-serum's HLL binding protein was at least 6-fold higher than the rubber particle binding protein to small rubber particles, providing a plausible explanation for the colloidal stability of latex under normal conditions [57].

In addition to these studies, a recent report on the latex coagulation mechanism of $H$. brasiliensis (Willd. ex A. Juss.) Müll. Arg. (Euphorbiaceae) showed chitinase and glucanase in primary and secondary lutoids to be playing a crucial role in rubber particle aggregation in the plant [115]. Under normal conditions, chitinase does not interact with glucanase. However, upon wounding or any mechanical damage, fresh latex flows out and the turgor pressure from laticifers suddenly decreases. This pressure decrease results in bursting of the lutoids. Consequently, the membraneembedded hevamine interacts with membrane-localized glucanase facilitating the rubber particle aggregation and subsequent rubber latex coagulation. Finally, latex vessels become plugged with rubber coagulates, which stops the latex flow $[46,115]$. Apart from the role of proteins on rubber particle aggregation connected to latex coagulation, the effects of other chemical factors such as enzymes and reactive oxygen species have been investigated $[116,117]$. The activity of enzymes such as peroxidase, catalase, and PPO have been well characterized in T. officinale $\mathrm{L}$. (Asteraceae), Taraxacum kok-saghyz L. E. Rodin (Asteraceae), and other latex-bearing plants [116]. Especially in Taraxacum species, PPO activity is one of the main factors controlling the coagulation mechanism. The rate of latex coagulation was found to be strongly correlated with the level of laticifer-specific PPO activity in Ficus elastica Roxb. ex. Hornem (Moraceae) and some Asteraceae plants, but not in H. brasiliensis (Willd. ex A. Juss.) Müll. Arg. (Euphorbiaceae). These findings show that the coagulation chemical processes are species dependent. However, it is important to bear in mind that coagulation processes do not involve only chemical changes but can also involve physical factors [118]. Physical differences such as rubber particle size, temperature, and water evaporation can also have a significant influence on the coagulation process. Larger particle sizes provide a larger surface area for rubber particle contact during rubber aggregation, leading most likely to different coagulation speed amongst species [118]. Besides, water evaporation speed at the latex plug contributes to the reduction of the latex coagulum volume, also increasing the rubber particles collision frequency and, consequently, the coagulation speed [118].

The speed of water evaporation is affected by environmental factors such as temperature and humidity. For example, high temperature combined with low humidity can produce faster water evaporation and faster coagulation. In general, different latex coagulation mechanisms seem to occur not only among different plant families but also among species belonging to the same plant family [118]. However, if one would ignore differences in specific coagulation factors and instead would focus on chemical families, it could be possible to find a general principle in latex coagulation process in rubbery latexes at least. This common trend always involves the rubber and protein fractions, plus the main environmental factors, temperature and humidity, and their physico- 
chemical consequences such as divalent cation stoichiometric ratios and $\mathrm{pH}$ changes.

In this regard, here we propose a general model for latex coagulation involving 4 general steps. The first step is an "equilibrium state." In these conditions, the laticifers are in normal physiological conditions and not disrupted by any mechanical rupture. All latex components such as lutoids, Frey-Wyssling complexes, rubber particles, specialized metabolites, and coagulant and anticoagulant proteins are suspended in the $\mathrm{C}$-serum at neutral $\mathrm{pH}$. The negatively charged rubber particles help to stabilize the latex colloidal suspension by negative-negative charge repulsion [49, 119121]. In the second step, "laticifer rupture," the strong decrease of pressure plus the entrance of water by apoplastic transport through the vascular bundles lead to the lysis of the lutoids [36]. After the cells burst, $\mathrm{Ca}^{2+}$ and $\mathrm{Mg}^{2+}$ ions are released into the Cserum [121]. Then an electrostatic interaction between the positive charges of the released ions and the negative charges of the rubber particles start the rubber aggregation process. After this and depending on the bursting lutoid index (number of broken lutoids), the concentration of coagulant proteins will surpass the concentration of anticoagulant proteins, as occurs in $\mathrm{H}$. brasiliensis (Willd. ex A. Juss.) Müll. Arg. (Euphorbiaceae) [56, 115]. This phenomenon reinforces the process of rubber aggregation. The presence of exposed lutoid membranes attached with positively charged proteins additionally serves as an agglutination factor. These membrane complexes are very specific for rubber particle recognition in rubber aggregation, working as a bridge for rubber particle interconnections. After this, all of the agglutinated particles and the secondary metabolites start to move carried by the out flow to the rupture point, in a manner comparable to Brownian diffusion. Because of this, all of the lutoidic components will be concentrated at one single point lowering the $\mathrm{pH}$ at the damage point. This acidifying effect rises the coagulation speed [122].

In a third step, the "plug formation," the latex mass starts to lose water because of the environmental temperature and humidity. The resulting volume reduction increases the concentration of solutes and the collision frequency among the rubber aggregates, which could remove the phospholipidic membrane covering the rubber particles and activate the rubber elongation factor [123]. The activation of this processes starts the coalescence among free-membrane rubber structures to produce a bigger rubber polymer [118]. At this point the rubber polymerization has reached an irreversible state. Finally, in the fourth step, "plug polymerization," the latex plug is completely dry and the plug has been transformed into a polymer composed of rubber, ions, residues of lutoid membranes, and protein complexes ( $\bullet$ Fig. 2 ). This dried plug is able to completely seal the injury, avoiding the loss of water and other metabolites. It can also obstruct the entrance of pathogenic microorganisms to the plant vascular system. In addition to this, in this polymeric cover there is a mixture of extremely high concentrated specialized metabolites and proteins that confer additional chemical protection against herbivores via toxicity or deterrence ( $\bullet$ Fig. 2).

\section{Endophytes-plant interactions shapes chemical profile of plants and their exudates}

Endophytes are defined as any microorganism that intra- or extracellularly colonizes healthy plant tissues without causing apparent pathologic symptoms [124]. They have been isolated from scale primordia to diverse plant organs such as roots or even resin ducts [125-128]. During plant-microorganism interactions, plants limit the development of endophytic populations, obliging these endophytes to evolve several biochemical strategies to gradually adapt to their new living environments [129]. This adaptation involves circumventing several physical and chemical barriers that must be overcome to establish a successful association [130]. In this context, the balanced antagonism hypothesis was initially proposed to address how an endophyte avoids the activation of the host immune system $[131,132]$. This hypothesis explains how microorganisms become resistant to toxic host metabolites and how they increase their population density without causing visible manifestations of infection $[133,134]$.

Taking into account the fact that endophytes reside within plants and are continuously interacting with their hosts, it is conceivable that plants have a substantial influence on the metabolic processes of endophytes and vice versa [135]. As examples, plant homoserine and asparagine act as host signals to activate the expression of a lethal gene in virulent strains of Nectria haematococ$c a$, which is only expressed in planta [10], and a camptothecinproducing endophyte, Fusarium solani, has been isolated from Camptotheca acuminate [11]. This endophyte was able to produce the precursors of camptothecin locally. Therefore, this type of plant-microorganism interaction raises the possibility of various recognized "plant metabolites" to actually be the metabolic products of their endophytes [136].

\section{Endophytic microorganisms inhabiting latex?}

As previously mentioned, most of the plant exudates contain a large spectrum of active specialized metabolites and biomolecules. In this context, it is unlikely that they could act as possible niche for microorganisms. However, as usually happens in nature, nothing is $100 \%$ certain. Consider, for example, that the role of herbivores in the transmission of bacteria that can later behave as endophytes has already been proven [137]. In that case even if not discussed by the authors, it is possible that the phloem could be as disperser of the bacterial community to all of the organs of the plant. Thus, plant exudates could also have a role on the distribution of endophytic population within individual plants.

Specifically, in the case of latexes, some trypanosomatids and other monoflagellate microorganisms have been isolated for the first time from the laticifers of Euphorbia hirta L. (Euphorbiaceae) on the island of Mauritius [138]. Furthermore, infections in others Euphorbia species produced no evident effects on plant growth or yield. Actually, the latex of parasitized and non-parasitized plants was microscopically undistinguishable $[139,140]$. This could reflect an equilibrium between plant host and microorganisms, avoiding infectious interactions and maybe establishing an endophytic-plant interaction instead.

One more example that could prove the existence of endophytic microorganisms in latexes was observed in papaya (Carica papaya L., Caricaceae) shoots. After cutting them, the shoots 
exude latex, containing phenolics and pigments that represent a common problem for the initiation of plant tissue culture from field stocks [141-147]. The bacteria appear as a cloudy dispersion mimicking a latex exudation. Eleven strains have been isolated from these cultures, 10 Gram-negative (5X Ralstonia mannitolilytica, 2X Paenibacillus sp, 2x Sphingomonas sp., 1X Pantoea spp.) and 1 Gram-positive isolate (Lysinibacillus fusiformis) [141].

Recently, in Euphorbia latex, a study measuring communities using culture-independent methods unexpectedly revealed complex bacterial (mean: 44 species per sample; 9 plants analyzed) and fungal (mean: 20.9 species per sample; 22 plants analyzed) communities contained in these latexes [148]. Many of the identified taxa are known plant endophytes but have not been found in latex previously. All of these examples show how even if plant exudates are a hostile environment for microbial development, some are capable of adapting to such an environment. Other intriguing aspects that have not been considered include the following: if latexes are chemically differentiated from their bearing tissues, is also their microbiome differentiated from their bearing tissues? If so, is this microbial differentiation correlated to their chemical discrimination? How do microorganisms produce their own metabolites, are they controlled by plant signaling, do they biotransform plant metabolites, or are they a separate symbiotic defense system? Therefore, the study of associated microbial communities in plant exudate structures and their bearing tissues will contribute to the understanding of plant exudates chemical diversity and selection.

\section{Latex as a bioactive chemical resource}

Historically, latexes have been used as medicinal substances by diverse cultures across the world from the Brazilian Amazonians to Indian users $[149,150]$. One of the best documented examples is the opium poppy (Papaver somniferum L., Papaveraceae). The oldest evidence of the relation between this material and mankind was found in the Mediterranean region in northwestern Italy [151], where well conserved seeds of opium poppy-which apparently were grown for food, oil, and medicine production or possibly for religious cult purposes-were found [151]. Nowadays, latex-bearing plants are still of great importance for the industrial sector. H. brasiliensis (Willd. ex A. Juss.) Müll. Arg. (Euphorbiaceae) is currently the main source of natural rubber in the world, and none of the synthetically produced rubber products have surpassed the quality obtained from this tree [152]. Furthermore, Parthenium argentatum A. Gray (Asteraceae) and T. kok-saghyz L. E. Rodin (Asteraceae) are 2 species used for the production of hypoallergenic and tire latex, respectively $[152,153]$.

In addition, the coagulation mechanisms of latex defense have been used as a bio-inspirational source for the production of selfhealing materials [154-156]. Bio-inspiration implies the conscious application of an idea or a system from nature [156]. In this regard, the inherent protective capacity of latexes can be applied not only in the production of healing materials, but in the understanding of the selection of bioactive metabolites by plants $[4,5$, 7]. Moreover, one should consider the fact that as usually occurs when a plant exudate flows out of its reservoir during plant-organism interactions, the attackers are not exposed to single compounds but to a certain combination of them $[157,158]$. Thus, latexes can also provide a clue of the potentiation mechanisms (e.g., synergism or additive effects) of plant chemical mixtures. This would help to unravel how plants combine these specialized metabolites to achieve bioactive mixtures for their self-defense. In this context, once unraveled, the mechanisms of plant chemical selection and their potentiation, the bio-inspiration concept can be potentially applied to the selection of bioactive metabolites and the design of their chemical mixtures against pathogenic microorganisms or insect pests. Therefore, summarizing the socioeconomic impact of the different latex-bearing plants plus their already renowned biological activities such as antibacterials, antifungals, cytotoxicity herbivore deterrence, and insecticidal effects further corroborates and reinforces the use of plant latex as a source of bioactive metabolites.

\section{Conclusions}

The literature strongly suggests that latex is an adaptive response to environmental factors, especially associated to biotic stress such as herbivory. However, latex is able to affect both prokaryotic and eukaryotic organisms. The great amount of generally toxic compounds in latexes can account for the secondary effect against microbial agents. Moreover, among all the plant exudates, their physical and highly diverse chemical composition makes them the ultimate defense against herbivores in nature. Taking into consideration all the diverse metabolites and mechanisms contained in plant exudates and especially in latexes, it is quite clear that the key factor for plant survival in the arms race against biotic factors is their physiological and chemical complexity. In this regard, plant exudates and especially latexes represent models to unravel plant chemical mixtures resulted from successful evolutionary defensive adaptations. The search for answers to the still unknown mechanisms of plant exudates will lead to a deeper understanding of the complex network of specialized metabolites interactions, complementation, and potentiation. Therefore, the inherent defensive origin of latexes is their most valuable character as an alternative source of bioactive metabolites and possibly their combination, especially in a time where mankind is running out of active molecules and pest and microbial resistance becomes a more common problem every day.

\section{Acknowledgements}

Mr. Luis Francisco Salomé-Abarca thanks the Mexican Scientific Council (CONACyT) for supporting his PhD scholarship (No. 410812).

\section{Conflict of Interest}

The authors declare that they have no conflict of interest.

References

[1] Coppen JJ. Gums, Resins and Latexes of Plant Origin. Rome: Food and Agriculture Organization of the United Nations; 1995: IX-X

[2] Dell B, McComb AJ. Plant resins - their formation, secretion and possible functions. Adv Bot Res 1977; 6: 277-316 
[3] Agrawal AA, Lajeunesse M], Fishbein M. Evolution of latex and its constituent defensive chemistry in milkweeds (Asclepias): a phylogenetic test of plant defense escalation. Entomol Exp Appl 2008; 128: 126-138

[4] Agrawal AA, Konno K. Latex: a model for understanding mechanisms, ecology, and evolution of plant defense against herbivory. Annu Rev Ecol Evol Syst 2009; 40: 311-331

[5] Konno K. Plant latex and other exudates as plant defense systems: roles of various defense chemicals and proteins contained therein. Phytochemistry 2011; 72: 1510-1530

[6] Huber M, Triebwasser-Freese D, Reichelt M, Heiling S, Paetz C, Bartram S, Schneider B, Gershenzon J, Erb M. Identification, quantification, spatiotemporal distribution and genetic variation of major latex secondary metabolites in the common dandelion (Taraxacum officinale agg.). Phytochemistry 2015; 115: 89-98

[7] Ramos MV, Grangeiro TB, Freire EA, Sales MP, Souza DP, Araújo ES, Freitas CDT. The defensive role of latex in plants: detrimental effects on insects. Arthropod Plant Interact 2010; 4: 57-67

[8] Langenheim JH. Plant Resins: Chemistry, Evolution, Ecology, and Ethnobotany. Portland: Cambridge; 2003: 49-50

[9] Termentzi A, Fokialakis N, Skaltsounis AL. Natural resins and bioactive natural products thereof as potential anitimicrobial agents. Curr Pharm Des 2011; 17: 1267-1290

[10] Yang Z, Rogers LM, Song Y, Guo W, Kolattukudy PE. Homoserine and asparagine are host signals that trigger in planta expression of a pathogenesis gene in Nectria haematococca. Proc Natl Acad Sci U S A 2005; 102: 4197-4202

[11] Kusari S, Zühlke S, Spiteller M. An endophytic fungus from Camptotheca acuminata that produces camptothecin and analogues. J Nat Prod 2009; 72: 2-7

[12] Choudhary PD, Pawar HA. Recently investigated natural gums and mucilages as pharmaceutical excipients: an overview. J Pharm 2014; 2014: 1-9

[13] Hirst EL, Jones JKW. The Gums and Mucilages of Plants. In: Åberg B, Albaum HG, Arnold A, Badenhuizen NP, Bourne EJ, Dangschat G, Fåhraeus G, Fischer H, Foster AB, Goerdeler J, Gottschalk A, Hassid WZ, Haurowitz F, Helder RJ, Henglein FA, Hirst EL, Jones JKN, Jucker E, Kerstan G, Lovern JA, EV Miller, Neumüller G, Preston RD, Rånby BG, Shafizadeh F, Stacey M, Stoll A, Veibel S, Vollmert B, Wagner A, Wanner H, Weber H, Whelan WJ, Wolf J, Wolfrom ML, Gordon-Young E, eds. Aufbau - Speicherung · Mobilisierung und Umbildung der Kohlenhydrate/Formation . storage - mobilization and transformation of carbohydrates. Handbuch der Pflanzenphysiologie/Encyclopedia of Plant Physiology. Berlin, Heidelberg: Springer; 1958: 500-504

[14] Sun Y, Tan DY, Baskin CC, Baskin JM. Role of mucilage in seed dispersal and germination of the annual ephemeral Alyssum minus (Brassicaceae). Aust J Bot 2012; 60: 439-449

[15] Dhifi W, Bellili S, Jazi S, Bahloul N, Mnif W. Essential oils' chemical characterization and investigation of some biological activities: a critical review. Medicines 2016; 3: 1-16

[16] Vainstein A, Lewinsohn E, Pichersky E, Weiss D. Floral fragrance. New inroads into an old commodity. Plant Physiol 2001; 27: 1383-1389

[17] Pophof B, Stange G, Abrell L. Volatile organic signals in a plant-herbivore system: electrophysiological responses in olfactory sensilla of the moth Cactoblastis cactorum. Chem Senses 2005; 30: 51-68

[18] Zhang B, Tolstikov V, Turnbull C, Hicks LM, Fiehn O. Divergent metabolome and proteome suggest functional independence of dual phloem transport systems in cucurbits. Proc Natl Acad Sci U S A 2010; 107: 13532-13537

[19] Gaupels F, Ghirardo A. The extrafascicular phloem is made for fighting. Front Plant Sci 2013; 4: 187

[20] Turgeon R, Oparka K. The secret phloem of pumpkins. Proc Natl Acad Sci U S A 2010; 107: 13201-13202
[21] Kehr ]. Phloem sap proteins: their identities and potential roles in the interaction between plants and phloem-feeding insects. J Exp Bot 2006; 57: 767-774

[22] Hunter JR. Reconsidering the functions of latex. Trees 1994; 9: 1-5

[23] Polhamus LG. Rubber: Botany, Production, and Utilization. New York: Interscience; 1962: 191-192

[24] Metcalfe CR. Distribution of latex in the plant kingdom. Econ Bot 1967; 21: 115-125

[25] Esau K. Plant Anatomy. 2nd ed. New York: Wiley; 1965: 484-487

[26] Webster CC, Baulkwill W]. Rubber. New York: Longman Scientific \& Technical; 1989: 84

[27] Cai X, Li W, Yin L. Ultrastructure and cytochemical localization of acid phosphatase of laticifers in Euphorbia kansui Liou. Protoplasma 2009; 238: $3-10$

[28] Pandey BP. Plant Anatomy. 6th ed. New Delhi: S. Chand and Company; 2001; 57-58

[29] Taira T, Ohdomar A, Nakama N, Shimoji M, Ishihara M. Characterization and antifungal activity of Gazyumaru (Ficusmicrocarpa) latex chitinases: both the chitin-binding and the antifungal activities of class I chitinase are reinforced with increasing ionic strength. Biosci Biotechnol Biochem 2005; 69: 811-818

[30] Karban R, Baldwin TT. Induced Responses to Herbivory. Chicago: University of Chicago Press; 1997: 3-4

[31] Bauer G, Friedrich C, Gillig C, Vollrath F, Speck T, Holland C. Investigating the rheological properties of native plant latex. J R Soc Interface 2013; 11: 20130847

[32] Agrawal AA. Natural selection on common milkweed (Asclepias syriaca) by a community of specialized insect herbivores. Evol Ecol Res 2005; 7: 651-667

[33] Hagel JM, Yeung EC, Facchini PJ. Got milk? The secret life of laticifers. Trends Plant Sci 2008; 13: 631-639

[34] Fahn A. Plant Anatomy. 3rd ed. Oxford: Pergamon Press; 1982: 142

[35] Mahlberg PG. Laticifers: an historic perspective. Bot Rev 1993; 59: 1-23

[36] Pickard WF. Laticifers and secretory ducts: two other tube systems in plants. New Phytol 2008; 177: 877-888

[37] Sacchetti G, Ballero M, Serafini M, Romagnoli C, Bruni A, Poli F. Laticifer tissue distribution and alkaloid location in Vincasardoa (Stearn) Pign. (Apocynaceae), an endemic plant of Sardinia (Italy). Phyton 1999; 39: 265-275

[38] Bouteau F, Dellis O, Bousquet U, Rona JP. Evidence of multiple sugar uptake across the plasma membrane of laticifer protoplasts from Hevea. Bioelectrochem Bioenerg 1999; 48: 135-139

[39] Cook SA, Sekhar BC. Fractions from Hevea brasiliensis latex centrifuged at 59, 000 g. J Rubb Res Inst Malaya 1955; 14: 163-167

[40] d'Auzac J, Crétin H, Marin B, Lioret C. A plant vacuolar system: the lutoids from Hevea brasiliensis latex. Physiol Vég 1982; 20: 311-331

[41] Hébant C. Ontogénie des laticifères du système primaire de l'Hevea brasiliensis: une étudeultrastructurale et cytochimique. Can J Bot 1981; 59 : 974-985

[42] Pujarniscle S. Caractèrelysosomal des lutoïdes du latex d'Heuea brasiliensis. Physiol Vég 1968; 6: 27-46

[43] Dupont J, Moreau F, Lance C, Jacob J. Phospholipid composition of the membrane of lutoids from Hevea brasiliensis latex. Phytochemistry 1976; 15: 1215-1217

[44] Frey-Wyssling A. Microscopic investigations on the occurrence ofresins in Hevea latex. Arch Rubber Cult 1929; 13: 392-412

[45] Sánchez-Ferrer A, Rodríguez-López JN, Garciía-Cánovas F, GarcíaCarmona F. Tyrosinase: a comprehensive review of its mechanism. Biochim Biophys Acta 1995; 1247: 1-11

[46] Wahler D, Schulze-Gronover C, Richter C, Foucu F, Twyman RM, Moerschbacher BM, Fischer R, Muth J, Prüfer D. Polyphenoloxidase 
silencing affects latex coagulation in Taraxacum species. Plant Physiol 2009; 151: 334-346

[47] Van Beilen JB, Poirier Y. Establishment of new crops for the production of natural rubber. Trends Biotechnol 2007; 25: 522-529

[48] Nor HM, Ebdon JR. Telechelic liquid natural rubber: a review. Prog Polym Sci 1998; 23: 143-177

[49] Wititsuwannakul D, Rattanapittayaporn A, Wititsuwannakul R. Rubber biosynthesis by a Hevea latex bottom-fraction membrane. J Appl Polym Sci 2003; 87: 90-96

[50] Bushman BS, Scholte AA, Cornish K, Scott DJ, Brichta JL, Vederas JC, Ochoa O, Michelmore RW, Shintani DK, Knapp SJ. Identification and comparison of natural rubber from two Lactuca species. Phytochemistry 2006; 67: 2590-2596

[51] Mooibroek H, Cornish K. Alternative sources of natural rubber. Appl Microbiol Biotechnol 2000; 53: 355-365

[52] Pintus F, Medda R, Rinaldi AC, Spanò D, Floris G. Euphorbia latex biochemistry: complex interactions in a complex environment. Plant Biosyst 2010; 144: 381-391

[53] Usha-Rani P, Jyothsna Y. Biochemical and enzymatic changes in rice as a mechanism of defense. Acta Physiol Plant 2010; 32: 695-701

[54] Gulsen O, Eickhoff T, Heng-Moss T, Shearman R, Baxendale F, Sarath G, Lee $D$. Characterization of peroxidase changes in resistant and susceptible warm season turf grasses challenged by Blissus occiduus. Arthropod Plant Interact 2010; 4: 45-55

[55] Gidrol X, Chrestin H, Tan HL, Kush A. Hevein, a lectin-like protein from Hevea brasiliensis (Rubber Tree) is involved in the coagulation of latex. J Biol Chem 1994; 269: 9278-9283

[56] Wititsuwannakul R, Pasitkul P, Jewtragoon P, Wititsuwannakul D. Hevea latex lectin binding protein in C-serum as an anti-latex coagulating factor and its role in a proposed new model for latex coagulation. Phytochemistry 2008; 69: 656-662

[57] Wang Y, Yang L, Chen X, Ye T, Zhong B, Liu R, Wu Y, Chan Z. Major latex protein-like protein 43 (MLP43) functions as a positive regulator during abscisic acid responses and confers drought tolerance in Arabidopsis thaliana. J Exp Bot 2016; 67: 421-434

[58] Zielińska S, Jezierska-Domaradzka A, Wójciak-Kosior M, Sowa I, Junka A, Matkowski AM. Greater celandine's ups and downs-21 centuries of medicinal uses of Chelidonium majus from the viewpoint of today's pharmacology. Front Pharmacol 2018; 9: 299

[59] Decker G, Wanner G, Zenk MH, Lottspeich F. Characterization of proteins in latex of the opium poppy (Papaver somniferum) using two-dimensional gel electrophoresis and microsequencing. Electrophoresis 2000; 21: 3500-3516

[60] Cho WK, Jo Y, Chu H, Park SH, Kim KH. Integration of latex protein sequence data provides comprehensive functional overview of latex proteins. Mol Biol Rep 2014; 41: 1469-1481

[61] Nawrot R. Defense-related proteins from Chelidonium majus L. as important components of its latex. Curr Protein Pept Sci 2017; 18: 864880

[62] Gulsen O, Eickhoff T, Heng-Moss T, Shearman R, Baxendale F, Sarath G, Lee $D$. Characterization of peroxidase changes in resistant and susceptible warm season turf grasses challenged by Blissus occiduus. Arthropod Plant Interact 2010; 4: 45-55

[63] Vandenborre G, Smagghe G, Van Damme E]. Plant lectins as defense proteins against phytophagous insects. Phytochemistry 2011; 72: $1538-1550$

[64] Chakraborti D, Sarkar A, Mondal HA, Das S. Tissue specific expression of potent insecticidal, Allium sativum leaf agglutinin (ASAL) in important pulse crop, chickpea (Cicer arietinum L.) to resist the phloem feeding Aphis craccivora. Transgenic Res 2009; 18: 529-544

[65] Saha P, Majumder P, Dutta I, Ray T, Roy SC, Das S. Transgenic rice expressing Allium sativum leaf lectin with enhanced resistance against sap-sucking insect pests. Planta 2006; 223: 1329-1343
[66] Macedo MLR, Freire MGM, Silva MBR, Coelho LC. Insecticidal action of Bauhinia monandra leaf lectin (BmoLL) against Anagasta kuehniella (Lepidoptera: Pyralidae), Zabrotes subfasciatus and Callosobruchus maculatus (Coleoptera: Bruchidae). Biochem Physiol A Mol Integr Physiol 2007; 146: 486-498

[67] Barbieri L, Falasca A, Franceschi C, Licastro F, Rossit CA, Stirpe F. Purification and properties of two lectins from the latex of the euphorbiaceous plants Hura crepitans L. (sand-box tree) and Euphorbia characias L. (Mediterranean spurge). Biochem J 1983; 215: 433-439

[68] Ryan CA. Protease inhibitors in plants: genes for improving defenses against insects and pathogens. Annu Rev Phytopathol 1990; 28: 425449

[69] Kim JS, Kim YO, Ryu H], Kwak YS, Lee JY, Kang H. Isolation of stressrelated genes of plant particles and latex in fig tree (Ficus carica) and their expressions by abiotic stress or plant hormone treatments. Plant Cell Physiol 2003; 44: 412-414

[70] Azarkan M, Wintjens R, Looze Y, Baeyens-Volant D. detection of three wound-induced proteins in papaya latex. Phytochemistry 2004; 65: 525-534

[71] Kant MR, Jonckheere W, Knegt B, Lemos F, Liu J, Schimmel BC], Villarroel CA, Ataide LMS, Dermauw W, Glas JJ, Egas M, Janssen A, Van Leeuwen T, Schuurink RC, Sabelis MW, Alba JM. Mechanisms and ecological consequences of plant defence induction and suppression in herbivore communities. Ann Bot 2015; 115: 1015-1051

[72] Dussourd DE. Entrapment of aphids and whiteflies in lettuce latex. Ann Entomol Soc Am 1995; 88: 163-172

[73] Pasteels JM, Gregoire JC. The chemical ecology of defense in arthropods. Ann Rev Entomol 1983; 28: 263-289

[74] Seiber JN, Nelson C], Lee SM. Cardenolides in the latex and leaves of seven Asclepias species and Calotropis procera. Phytochemsitry 1982; 21: $2343-2348$

[75] Konno K, Hirayama C, Nakamura M, Tateishi K, Tamura Y, Hatori M, Konno K. Papain protects papaya trees from herbivorous insects: role of cysteine protease in latex. Plant J 2004; 37: 370-378

[76] Konno K, Ono M, Nakamura M, Tateishi K, Hirayama C, Tamura Y, Hatori $\mathrm{M}$, Konno K. Mulberry latex rich in antidiabetic sugar-mimic alkaloids forces dieting on caterpillars. Proc Natl Acad Sci U S A 2006; 103: 1337-1341

[77] Sessa R, Benett MH, Lewin M], Mansfirls JW, Beale MH. Metabolite profiling of sesquiterpene lactones from Lactuca species. J Biol Chem 2000; 275: $26877-26884$

[78] Noack EA, Crea AE, Falsone G. Inhibition of mitochondrial oxidative phosphorylation by 4-deoxyphorboltriester, a poisonous constituent of the latex sap of Eupborbia biglantdtlosa Desf. Toxicon 1980; 18: 165-174

[79] Gershenzon J, Croteau R. Terpenoids. In: Rosenthal GA, Berenbaum MR eds. Herbivores: Their Interactions with secondary Plant Metabolites. Vol. 1: The Chemical Participants. 2nd ed. London: Academic Press Inc; 1991: 165-219

[80] Mazid M, Khan TA, Mohammad F. Role of secondary metabolites in defense mechanisms of plants. Biol Med 2011; 3: 232-249

[81] Heftmann E. Steroid hormones in plants. J Nat Prod 1975; 38: 195-209

[82] Mazoir N, Benharref A, Bailén M, Reina M, González-Coloma A. Bioactive triterpene derivatives from latex of two Euphorbia species. Phytochemistry 2008; 69: 1328-1338

[83] Giner JL, Berkowitz JD, Andersson T. Nonpolar components of the latex of Euphorbia peplus. J Nat Prod 2000; 63: 267-269

[84] Hjgigh-Valitova JN, Sulkarnayeva AG, Minibayeva FV. Plant sterols: diversity, biosynthesis, and physiological functions. Biochem (Mosc) 2016; 81: 819-834

[85] Malcolm SB. Cardenolide-Mediated Interactions between Plants and Herbivores. In: Rosenthal GA, Berenbaum MR, eds. Herbivores: Their Interactions with secondary Plant Metabolites. Vol. 1: The chemical Participants. 2nd ed. Oxford, UK: Blackwell Scientific; 1991: 251-296 
[86] Glynn IM. The action of cardiac glycosides on sodium and potassium movements in human red cells. J Physiol 1957; 136: 148-173

[87] Repke KRH. New developments in cardiac glycoside structure-activity relationships. Trends Pharmacol Sci 1985; 6: 275-278

[88] Paula S, Tabet MR, Ball W]. Interactions between cardiac glycosides and sodiumpotassium-ATPase: three-dimensional structure-activity relationship models for ligand binding to the E2-Pi form of the enzyme versus activity inhibition. Biochemistry 2005; 44: 498-510

[89] Paul WCG, Veitch NC, Stevenson PC, Simmonds MS]. Cardenolides from Gomphocarpus sinaicus and Pergularia tomentosa (Apocynaceae: Asclepiadoideae) deter the feeding of Spodoptera littoralis. Arthropod Plant Interact 2011; 5: 219-225

[90] Huang X, Renwick JAA, Sachdev-Gupta K. A chemical basis for differential acceptance of Erysimum cheiranthoides by two Pieris species. J Chem Ecol 1993; 19: 195-210

[91] Huang X, Renwick JA. Cardenolides as oviposition deterrents to two Pieris species: structure-activity relationships. J Chem Ecol 1994; 20: 1039-1051

[92] Renwick JAA. Diversity and Dynamics of Crucifer Defenses against Adults and Larvae of Cabbage Butterflies. In: Romeo JT, Saunders JA, Barbosa P, eds. Recent Advances in Phytochemistry. Phytochemical Diversity and Redundancy in ecological Interactions. New York: Plenum Press; 1996: 57-79

[93] Akhtar Y, Rankin CH, Isman MB. Decreased response to feeding deterrents following prolonged exposure in the larvae of a generalist herbivore, Trichoplusia ni (Lepidoptera: Noctuidae). J Insect Behav 2003; 16 : 811-831

[94] Fukuyama Y, Ochi M, Kasai H, Kodama M. Insect growth inhibitory cardenolide glycosides from Anodendron affine. Phytochemistry 1993; 32: 297-301

[95] Carter CA, Gray EA, Schneider TL, Lovett CM, Scott L, Messer AC, Richardson DP. Toxicarioside B and toxicarioside C. New cardenolides isolated from Antiaris toxicaria latex-derived dart poison. Tetrahedron 1997; 53: 16959-16968

[96] Dai HF, Gan YJ, Que DM, Wu J, Wen ZC, Mei WL. A new cytotoxic 19Nor-cardenolide from the latex of Antiaris toxicaria. Molecules 2009; 14: 3694-3699

[97] Appel HM. Phenolics in ecological interactions: the importance of oxidation. J Chem Ecol 1993; 19: 1521-1552

[98] Ismun A, Ariffin MM, Razak SBA, Wei OC, Ahmad FT, Mubarak A. Determination of polyphenol contents in Hevea brasiliensis and rubber-processing effluent. MJAS 2018; 22: 185-196

[99] Snook ME. Characterization and quantification of hexadecyl, octadecyl and eicosyl esters of $p$-coumaric acid in the vine and root latex of sweet potato (Ipomoea batatas (L.) Lam.). J Agric Food Chem 1994; 42: 2589 2595

[100] Hegnauer R. Biochemistry, distribution and taxonomic relevance of higher plant alkaloids. Phytochemistry 1988; 21: 2423-2427

[101] Harborne JB. Introduction to ecological Biochemistry. 4th ed. San Diego: Academic Press Inc.; 1993: 186-201

[102] Hansen I, Brimer L, Mølgaard P. Herbivore-deterring secondary compounds in heterophyllous woody species of the Mascarene Islands. Perspect Plant Ecol Evol Syst 2003; 6: 187-203

[103] Macel M. Attract and deter: a dual role for pyrrolizidine alkaloids in plant-insect interactions. Phytochem Rev 2011; 10: 75-82

[104] Creelman RA, Mullet JE. Oligosaccharins, brassinolides, and jasmonates: nontraditional regulators of plant growth, development, and gene expression. Plant Cell 1997; 9: 1211-1223

[105] Tomè F, Colombo ML. Distribution of alkaloids in Chelidonium majus and factors affecting their accumulation. Phytochemistry 1995; 40: $37-39$
[106] Schmeller T, Latz-Brüning B, Wink M. Biochemical activities of berberine, palmatine and sanguinarine mediating chemical defense against microorganisms and herbivores. Phytochemistry 1997; 44: 257-266

[107] Samanani N, Alcantara J, Bourgault R, Zulak KG, Facchini PJ. The role of phloem sieve element and accumulation of alkaloids in opium poppy. Plant J 2006; 47: 547-563

[108] Weid M, Ziegler J, Kutchan TM. The roles of latex and the vascular bundle in morphine biosynthesis in the opium poppy, Papaver somniferum. Proc Natl Acad Sci U S A 2004; 101: 13957-13962

[109] Asano N, Nash RJ, Molyneux RJ, Fleet GWJ. Sugar-mimic glycosidase inhibitors: natural occurrence, biological activity and prospects for therapeutic application. Tetrahedron 2000; 11: 1645-1680

[110] Hirayama C, Konno K, Wasano N, Nakamura M. Differential effects of sugar-mimic alkaloids in mulberry latex on sugar metabolism and disaccharidases of Eri and domesticated silkworms: enzymatic adaptation of Bombyx mori to mulberry defense. Insect Biochem Mol Biol 2007; 37: 1348-1358

[111] Buttery BR, Boatman SG. Water Deficits and Flow of Latex. In: Kozlowski TT, ed. Water Deficits and Plant Growth. New York: Academic Press; 1976: 233-289

[112] Spencer HJ. The effect of puncturing individual latex tubes of Euphorbia wulfenii. Annals of Botany 1939; 3: 227-229

[113] Rasmann S, Agrawal AA, Cook SC, Erwin AC. Cardenolides, induced responses, and interactions between above- and belowground herbivores of milkweed (Asclepias spp.). Ecology 2009; 90: 2393-2404

[114] Bingham RA, Agrawal AA. Specificity and trade-offs in the induced plant defence of common milkweed Asclepias syriaca to two lepidopteran herbivores. J Ecol 2010; 98: 1014-1022

[115] Wang X, Wang D, Sun Y, Yang Q, Chang L, Wang L, Meng X, Huang Q, jin $X$, Tong $Z$. Comprehensive proteomics analysis of laticifer latex reveals new insights into ethylene stimulation of natural rubber production. Sci Rep 2015; 5: 13778

[116] Wang X, Shi M, Wang D, Chen Y, Cai F, Zhang S, Wang L, Tong Z, Tian WM. Comparative proteomics of primary and secondary lutoids reveals that chitinase and glucanase play a crucial combined role in rubber particle aggregation in Hevea brasiliensis. J Proteome Res 2013; 12: 5146-5159

[117] Zhang Y, Leclercq J, Montoro P. Reactive oxygen species in Hevea brasiliensis latex and relevance to tapping panel dryness. Tree Physiol 2017 . 37: 261-269

[118] Bauer G, Gorb SN, Klein MC, Nellesen A, von Tapavicza M, Speck T. Comparative study on plant latex particles and latex coagulation in Ficus benjamina, Campanula glomerata and three Euphorbia species. PLoS One 2014; 9: e113336

[119] Hierrezuelo J, Vaccaro A, Borkovec M. Stability of negatively charged latex particles in the presence of a strong cationic polyelectrolyte at elevated ionic strengths. J Colloid Interface Sci 2010; 347: 202-208

[120] Oncsik T, Trefalt G, Csendes Z, Szilagyi I, Borkovec M. Aggregation of negatively charged colloidal particles in the presence of multivalent cations. Langmuir 2014; 30: 733-741

[121] d'Auzac J, Jacob JL. The Composition of Latex from Hevea brasiliensis as a laticiferous Cytoplasm. In: d'Auzac J, Jacob JL, Chrestin H, ed. Physiology of Rubber Tree Latex. Boca Raton: CRC Press; 1989: 59-96

[122] de Oliveira-Reis G, Menut P, Bonfils F, Vaysse L, Hemar Y, Sanchez C. Acid-induced aggregation and gelation of natural rubber latex particles. Colloid Surf A Physicochem Eng Asp 2015; 482: 9-17

[123] Aoki Y, Takahashi S, Takayama D, Ogata Y, Sakurai N, Suzuki H, Asawatreratanakul K, Wititsuwannakul D, Wititsuwannakul R, Shibata D, Koyama T, Nakayama T. Identification of laticifer-specific genes and their promoter regions from a natural rubber producing plant Hevea brasiliensis. Plant Sci 2014; 225: 1-8

[124] Wilson D. Endophyte - the evolution of the term, a clarification of its use and definition. Oikos 1995; 73: 274-276 
[125] Pirttilä AM, Laukkanen H, Pospiech H, Myllyla R, Hohtola A. Detection of intracellular bacteria in the buds of Scotch pine (Pinus sylvestris L.) by in situ hybridization. Appl Environ Microbiol 2000; 66: 3073-3077

[126] Pirttilä AM, Pospiech H, Laukkanen H, Myllylä R, Hohtola A. Two endophytic fungi in different tissues of Scots pine buds (Pinus sylvestris L.). Microb Ecol 2003; 45: 53-62

[127] Hata K, Atari R, Sone K. Isolation of endophytic fungi from leaves of Pasania edulis and their within-leaf distributions. Mycoscience 2002; 43: 369-373

[128] Hata K, Sone K. Isolation of endophytes from leaves of Neolitsea sericea in broad leaf and conifer stands. Mycoscience 2008; 49: 229-232

[129] Dudeja SS, Sheokand S, Kumari S. Legume root nodule development and functioning under tropics and subtropics: perspectives and challenges. Legume Res 2012; 35: 85-103

[130] Kusari S, Hertweck C, Spiteller M. Chemical ecology of endophytic fungi: origins of secondary metabolites. Chem Biol 2012; 19: 792-798

[131] Schulz B, Römmert AK, Dammann U, Aust HJ, Strack D. The endophyte-host interaction: a balanced antagonism. Mycol Res 1999; 103: 1275-1283

[132] Schulz B, Boyle C. The endophytic continuum. Mycol Res 2005; 109 : 661-686

[133] Arnold AE. Understanding the diversity of foliar endophytic fungi: progress, challenges, and frontiers. Fungal Biol Rev 2007; 21: 51-66

[134] Schulz B, Boyle C. What are Endophytes? In: Schulz BJE, Boyle CJC, Sieber TN, eds. Microbial Root Endophytes. Berlin: Springer; 2006: 113

[135] Arnold AE. Endophytic Fungi: Hidden Components of tropical Community Ecology. In: Carson WP, Schnitzer SA, eds. Tropical Forest Community Ecology. West Sussex: Wiley-Blackwell; 2008: 254-271

[136] Kusari S, Spiteller M. Metabolomics of endophytic Fungi producing associated Plant secondary Metabolites: Progress, Challenges and Opportunities. In: Roessner U, ed. Metabolomics. Rijeka: InTech; 2012: 241-266

[137] López-Fernández S, Mazzoni V, Pedrazzoli F, Pertot I, Campisano A. A phloem-feeding insect transfers bacterial endophytic communities between grapevine plants. Front Microbiol 2017; 8: 1-17

[138] Lafont A. Sur la presence d'un Leptomonas, parasite de la classe des flagellés, dans le latex de l'Euphorbiapilulifera. C R Soc Biol 1909; 66: 1011-1013

[139] Bensaude M. Flagellates in plants: a review of foreign literature. Phytopathology 1925; 15: 273-281

[140] Aragão HB. Untersuchungen über Phytomonas françai. Mem Inst Oswaldo Cruz 1931; 25: 299-306

[141] George EF. Plant Propagation by Tissue Culture. 2nded. Edington, England: Exegetic Limited; 1993: 441

[142] Leifert C, Cassells AC. Microbial hazards in plant tissue and cell cultures. In Vitro Cell Dev Biol Plant 2001; 37: 133-138
[143] Thomas P. A three-step screening procedure for detection of covert and endophytic bacteria in plant tissue cultures. Curr Sci 2004; 87, $67-72$

[144] Thomas P. In vitro decline in plant cultures: detection of a legion of covert bacteria as the cause for degeneration of long-term micropropagated triploid watermelon cultures. Plant Cell Tissue Org Cult 2004; 77: $173-179$

[145] Thomas P, Kumari S, Swarna GK, Prakash DP, Dinesh MR. Ubiquitous presence of fastidious endophytic bacteria in field shoots and indexnegative apparently clean shoot-tip cultures of papaya. Plant Cell Rep 2007; 26: 1491-1499

[146] Thomas P, Swarna GK, Patil P, Rawal RD. Ubiquitous presence of normally non-cultivable endophytic bacteria in field shoot-tips of banana and their gradual activation to quiescent cultivable form in tissue cultures. Plant Cell Tissue Org Cult 2008; 93: 39-54

[147] Thomas P, Kumari S. Inconspicuous endophytic bacteria mimicking latex exudates in shoot-tip cultures of papaya. Sci Hort 2010; 124 : 469-474

[148] Gunawardana M, Hyde ER, Lahmeyer S, Dorsey BL, La Val TP, Mullen M, Yoo J, Knight R, Baum MM. Euphorbia plant latex is inhabited by diverse microbial communities. Am J Bot 2015; 102: 1966-1977

[149] Breitbach UB, Niehues M, Lopes NP, Faria JEQ, Brandão MGL. Amazonian Brazilian medicinal plants described by C.F.P. von Martius in the 19th century. J Ethnopharmacol 2013; 147: 180-189

[150] Verma RK. An ethnobotanical study of plants used for the treatment of livestock diseases in Tikamgarh District of Bundelkhand, Central India. Asian Pac J Trop Biomed 2014; 4: S460-S467

[151] Merlin MD. Archaeological evidence for the tradition of psychoactive plant use in the Old World. Econ Bot 2003; 57: 295-323

[152] Venkatachalam P, Geetha N, Sangeetha P, Thulaseedharan A. Natural rubber producing plants: an overview. Afr J Biotechnol 2013; 12: 1297-1310

[153] Siler DJ, Cornish K. Hypoallergenicity of guayule rubber particle proteins compared to Hevea latex proteins. Ind Crops Prod 1994; 2: $307-$ 313

[154] Cremaldi JC, Bhushan B. Bioinspired self-healing materials: lessons from nature. Beilstein J Nanotechnol 2018; 9: 907-935

[155] Anandan S, Rudolph A, Speck T, Speck O. Comparative morphological and anatomical study of self-repair in succulent cylindrical plant organs. Flora 2018; 241: 1-7

[156] Speck O, Speck T. An overview of bioinspired and biomimetic self-repairing materials. Biomimetics 2019; 4: 26

[157] Izhaki I. Emodin-a secondary metabolite with multiple ecological functions in higher plants. New Phytol 2002; 155: 205-217

[158] Kessler A, Kalske A. Plant secondary metabolite diversity and species interactions. Annu Rev Ecol Evol Syst 2018; 49: 115-138 